\title{
Stoichiometry and kinetics of mercury uptake by photosynthetic bacteria
}

\section{Mariann Kis, Gábor Sipka \& Péter Maróti}

\section{Photosynthesis Research}

Official Journal of the International Society of Photosynthesis Research

ISSN 0166-8595

Volume 132

Number 2

Photosynth Res (2017) 132:197-209

DOI 10.1007/s11120-017-0357-z

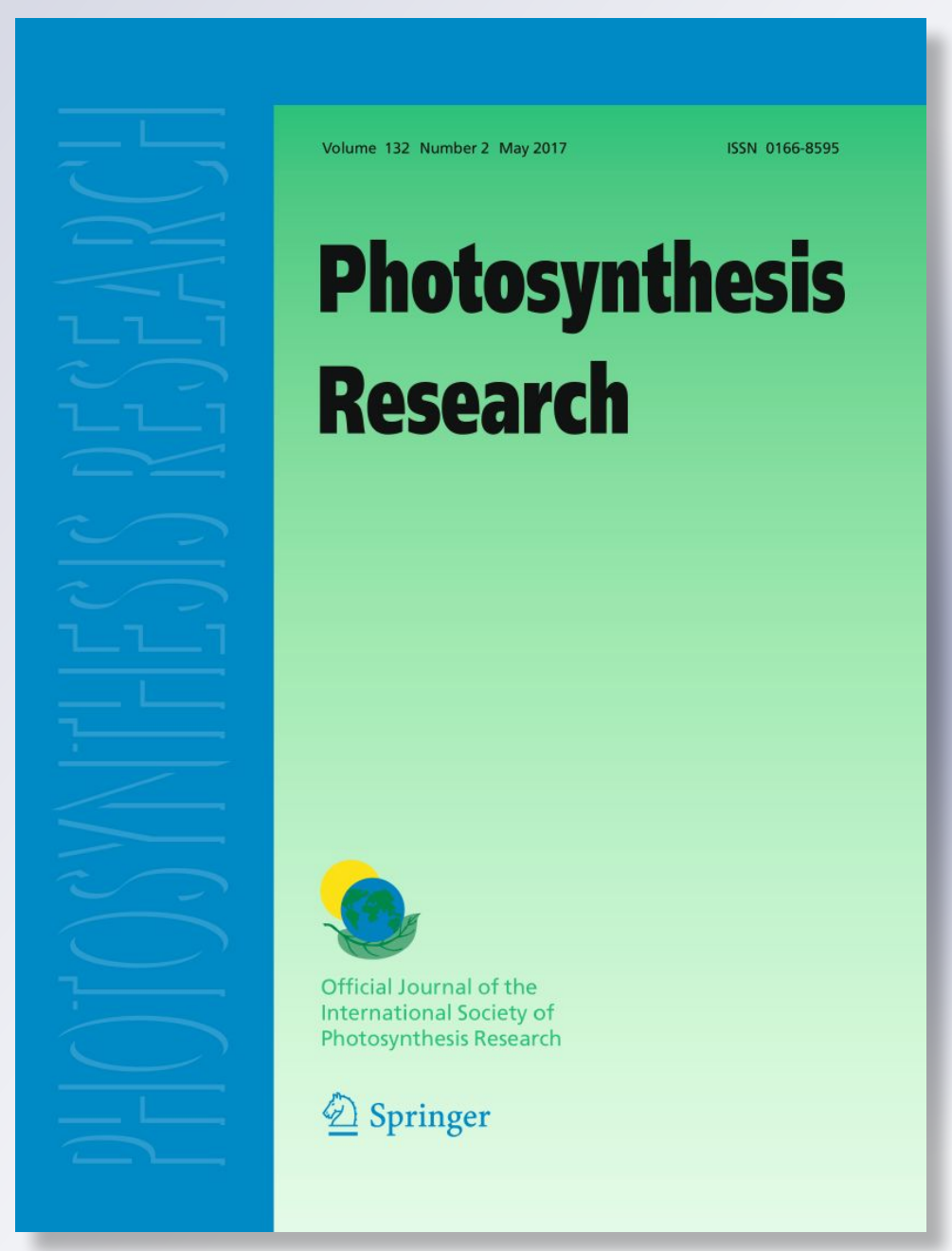

Springer 
Your article is protected by copyright and all rights are held exclusively by Springer Science +Business Media Dordrecht. This e-offprint is for personal use only and shall not be selfarchived in electronic repositories. If you wish to self-archive your article, please use the accepted manuscript version for posting on your own website. You may further deposit the accepted manuscript version in any repository, provided it is only made publicly available 12 months after official publication or later and provided acknowledgement is given to the original source of publication and a link is inserted to the published article on Springer's website. The link must be accompanied by the following text: "The final publication is available at link.springer.com". 


\title{
Stoichiometry and kinetics of mercury uptake by photosynthetic bacteria
}

\author{
Mariann Kis $^{1} \cdot$ Gábor Sipka $^{1} \cdot$ Péter Maróti $^{1}$
}

Received: 13 August 2016 / Accepted: 13 February 2017 / Published online: 4 March 2017

(c) Springer Science+Business Media Dordrecht 2017

\begin{abstract}
Mercury adsorption on the cell surface and intracellular uptake by bacteria represent the key first step in the production and accumulation of highly toxic mercury in living organisms. In this work, the biophysical characteristics of mercury bioaccumulation are studied in intact cells of photosynthetic bacteria by use of analytical (dithizone) assay and physiological photosynthetic markers (pigment content, fluorescence induction, and membrane potential) to determine the amount of mercury ions bound to the cell surface and taken up by the cell. It is shown that the $\mathrm{Hg}$ (II) uptake mechanism (1) has two kinetically distinguishable components, (2) includes co-opted influx through heavy metal transporters since the slow component is inhibited by $\mathrm{Ca}^{2+}$ channel blockers, (3) shows complex $\mathrm{pH}$ dependence demonstrating the competition of ligand binding of $\mathrm{Hg}(\mathrm{II})$ ions with $\mathrm{H}^{+}$ions (low $\mathrm{pH}$ ) and high tendency of complex formation of $\mathrm{Hg}(\mathrm{II})$ with hydroxyl ions (high $\mathrm{pH}$ ), and (4) is not a passive but an energy-dependent process as evidenced by light activation and inhibition by protonophore. Photosynthetic bacteria can accumulate $\mathrm{Hg}$ (II) in amounts much (about $10^{5}$ ) greater than their own masses by welldefined strong and weak binding sites with equilibrium binding constants in the range of $1(\mu \mathrm{M})^{-1}$ and $1(\mathrm{mM})^{-1}$, respectively. The strong binding sites are attributed to sulfhydryl groups as the uptake is blocked by use of sulfhydryl modifying agents and their number is much (two orders of magnitude) smaller than the number of weak binding sites. Biofilms developed by some bacteria (e.g., Rvx. gelatinosus) increase the mercury binding capacity further by a
\end{abstract}

Péter Maróti

pmaroti@sol.cc.u-szeged.hu

1 Institute of Medical Physics, University of Szeged, Rerrich Béla tér 1, Szeged 6720, Hungary factor of about five. Photosynthetic bacteria in the light act as a sponge of $\mathrm{Hg}$ (II) and can be potentially used for biomonitoring and bioremediation of mercury-contaminated aqueous cultures.

Keywords Bacterial photosynthesis $\cdot$ Intact cells · Spectroscopy $\cdot \mathrm{Hg}(\mathrm{II})$ contamination $\cdot$ Biomediation of the environment
Abbreviations
BChl Bacteriochlorophyll
$Q_{\mathrm{A}}$ and $Q_{\mathrm{B}}$ Primary and secondary quinone acceptors,
RC $\quad$ Reaction center

\section{Introduction}

After recognition of the transformation of metal compounds in the environment by non-phototrophic bacteria, bacterial processing of inorganic compounds became a topic of interest in the past decades (Kane et al. 2016). Several groups have demonstrated that photosynthetic bacteria are also able to metabolize metals and metalloids and became additional possible candidates in bioprotection and bioremediation of the environment (Mehta and Gaur 2005; Singh et al. 2009; Glick 2010). Trace metals essential (manganese, iron, cobalt, copper, zinc, etc.) or non-essential (e.g., mercury) for life can be either adsorbed on the cellular surface or taken up by passive/facilitated uptake through porins/channels or by active transport through the membrane. The adsorption occurs by several chemical/functional groups (Italiano et al. 2009) that attract and sequester pollutants (Abdi and Kazemia 2015). It is nonspecific, fast, and independent on the metabolism (Sloof 
et al. 1995; Chang et al. 1997; Bakkaloglu et al. 1998; Torres et al. 1998; Ahluwalia and Goyal 2007). On the other hand, the facilitated and active modes of uptake are slower and are closely connected to metabolic, enzymatic, and energetic processes of the cell (Malik 2004; Munoz and Guieysse 2006). The transport systems are driven either by the hydrolysis of ATP [e.g., ATP-binding cassette (ABC) transporters (Ma et al. 2009)] or by coupling to an energetically favorable transfer of protons [e.g., Nramp proteins (Nevo and Nelson 2006)].

To reveal the metal-binding mechanism, the pathways of metal adsorption and uptake should be studied separately. Although there have been many studies over the last decades describing metal homeostasis in numerous bacteria and many common patterns and homologous transporters/metallochaperones across diverse phyla (Youssef et al. 2015), there is no consensus on several essential points. Some investigators have shown that metabolic activity reduces the extent of bound metal ion due to competition with protons produced by living cells (Moore and Kaplan 1994; Gabr et al. 2008), while in other cases intact cells have shown higher affinity for heavy metal binding (Puranik and Paknikar 1999; Asztalos et al. 2010).

Among the heavy metals, mercury has a distinguished role due to its prevalence as a pollutant in aqueous systems and its very high toxicity to living organisms. Deeper understanding of $\mathrm{Hg}$ dynamics in anoxic environments with respect to methylation (resulting in an outmost toxic form of mercury) may involve ecological and environmental context. The mercury uptake by anoxygenic phototrophs as the primary step has severe influence on the cycling of inorganic $\mathrm{Hg}$ and methylmercury in the food web of anoxic environments. Field and laboratory experiments have shown that phototrophs can directly interact with $\mathrm{Hg}$ and abet its speciation and fate (Grégoire and Poulain 2014). Once mercury accumulates in aquatic food webs, it is biomagnified from bacteria, to plankton, through macroinvertebrates, to herbivorous fish and to piscivorous (fish-eating) fish (Wiener et al. 2003).

The mercuric ions seem to serve no biologically relevant function. Instead, they cause damage on different levels of the organism. By translocation of the mercury ions through the cell membranes, the intracellular metal-binding sites are exposed (Gourdon et al. 1990), which can ultimately result in the death of sensitive organisms unless a means of detoxification is induced or already possessed (Vijayadeep and Sastry 2014). The possible causal mechanisms of mercury toxicity are changes in the permeability of the cell membrane, reactions of sulphydryl groups, affinity for reacting with phosphate groups and active groups of ADP or ATP, and replacement of essential ions, mainly major cations (Fe from some iron-sulfur clusters) (Patra and Sharma 2000; Nabi 2014). Organic and inorganic mercurials have distinct effects on the disruption of protein-iron centers: inorganic mercury was found much more efficient at removing iron from iron-dependent proteins than organic mercury compounds in E. coli bacteria (LaVoie et al. 2015).

Photosynthetic organisms are vulnerable to mercury exposure: in photosynthetic bacteria of Rba. sphaeroides 2.4.1, the half lethal dose (concentration) is two or three orders of magnitude smaller than those of any other metal ions (Giotta et al. 2006; Asztalos et al. 2010). Mercury affects both light and dark reactions of bacterial photosynthesis and strongly inhibits the photosynthetic electron transport chain in which the reaction center (RC) protein is the most sensitive target (Asztalos et al. 2012; Kis et al. 2015). On the acceptor side, the Hg-induced inhibition is attributed to the damage of the interquinone electron transfer from $Q_{\mathrm{A}}$ to $Q_{\mathrm{B}}$ and/or to the increase of the fraction of closed RCs $\left(Q_{\mathrm{A}}^{-}\right)$. The donor side is much more resistant to $\mathrm{Hg}$ than the acceptor side. Although these data support that $\mathrm{Hg}(\mathrm{II})$ has no physiological function, it has been shown recently that $\mathrm{Hg}(\mathrm{II})$ might act in the presence of intracellular redox imbalance as sink of electrons to maintain redox homeostasis in purple bacteria (Gregoire and Poulain 2016).

Very little is known regarding the mechanism of uptake of inorganic $\mathrm{Hg}(\mathrm{II})$ by photosynthetic organisms, in part because of the inherent difficulty in measuring the intracellular mercury concentration. It has been revealed that $\mathrm{Hg}(\mathrm{II})$ uptake in anaerobic bacteria is an active transport process requiring energy and not a passive process as commonly perceived (Schaefer et al. 2011). The question can be asked whether cellular $\mathrm{Hg}$ uptake is specific for $\mathrm{Hg}$ (II), or accidental, occurring via some essential metal importer. $\mathrm{Hg}$ (II) uptake is highly dependent on the characteristics of the thiols that bind $\mathrm{Hg}$ (II) in the external medium. Some $\mathrm{Hg}(\mathrm{II})$ complexations by thiols promote the uptake and others inhibit the uptake. The evaluation of mercury binding mechanism of highly resistant marine bacteria (Deng and Wang 2012) and genetically engineered photosynthetic bacteria (Deng and Jia 2011) revealed that about $70 \%$ of $\mathrm{Hg}^{2+}$ was bound on the cell surface, and carboxyl groups played an important role in $\mathrm{Hg}^{2+}$ binding. The main resistance mechanisms are attributed either to accumulation of metalscavenging internal polypeptides or to membrane potentialdependent efflux of metals through different membrane transporters. Naturally occurring metal-binding peptides, such as metallothioneins and phytochelatins (Winklemann and Winge 1994; Sigel and Sigel 2009), are the main metal-sequestering molecules used by cells to immobilize metal ions, offering selective, high-affinity binding sites. Several genetically engineered organisms were constructed which expressed several metal-binding peptides attached to the $\mathrm{Hg}^{2+}$ transport system both at the cell surface and in the intracellular medium (Bae et al. 2001). The limited uptake 
across the cell membrane is often the rate-limiting factor for the intracellular bioaccumulation of heavy metals.

The interest of this paper was the establishment of stoichiometry and kinetic and energetic separation of different modes of mercury uptake in the frame of a molecular model of bioaccumulation of mercury by intact photosynthetic cells. Furthermore, the $\mathrm{Hg}^{2+}$ uptake was measured and compared quantitatively in different photosynthetic bacteria with special regard to their planktonic or biofilm mode of lives (Rvx. gelatinosus). Our research is aiming at (1) filling knowledge gaps in our understanding of the interplay between $\mathrm{Hg}$ cycle and photosynthesis and (2) facilitating the application of photosynthetic bacteria for mercury (metal) bioremediation and further rendering continuous treatment more feasible for industrial use.

\section{Materials and methods}

\section{Bacterial strains and growth conditions}

The photosynthetic purple bacterium Rubrivivax (Rvx.) gelatinous (wt), Rhodospirillum (Rsp.) rubrum (wt), and Rhodobacter (Rba.) sphaeroides 2.4.1 were grown in Siström's medium (Siström 1962) in completely filled screw top vessels without oxygen (anaerobic growth). The medium was inoculated from a dense batch culture (1:100) and was illuminated by tungsten lamps that assured $13 \mathrm{~W} \mathrm{~m}^{-2}$ irradiance on the surface of the vessel as described earlier (Asztalos et al. 2010). Planktonic cells of $R v x$. gelatinosus were harvested at an early exponential phase; biofilm cells were harvested at late stationary phase of growth where the cells were strongly connected by biofilms. The sample was bubbled with nitrogen for $15 \mathrm{~min}$ before measurements to preserve the anoxic conditions. The cell density (concentration) of the culture was estimated by counting the number of individual cells with calibrated Bürker chamber under light microscope.

\section{Chemicals}

For $\mathrm{Hg}^{2+}$ ion treatment of the bacteria, the mercuric ion was added to the culture in the form of $\mathrm{HgCl}_{2}$ (Giotta et al. 2006). 1 and $10 \mathrm{mM} \mathrm{HgCl} 2$ stock solutions were used which were freshly prepared before the experiment. $\mathrm{HgCl}_{2}$ is highly soluble in aqueous solution under physiological conditions and stable for the duration $(<1 \mathrm{~h})$ of the treatment. The bacterial samples were kept illuminated or in the dark under anoxic condition during the mercury treatment.

For $\mathrm{pH}$ dependence measurements, a cocktail of buffers (2-2 mM) was used: 2-(N-morpholino)-ethanesulfonic acid (MES; Sigma) between $\mathrm{pH} 5.5$ and $\mathrm{pH}$ 6.5; 1,3-bis[tris(hydroxymethyl) methylamino]propane]
(Bis-Tris propane; Sigma) between $\mathrm{pH} 6.3$ and $\mathrm{pH} 9.5$; Tris-HCl (Sigma) between pH 7.5 and pH 9.0; 3-(cyclohexylamino) propanesulfonic acid (CAPS; Calbiochem) above $\mathrm{pH}$ 9.5. The $\mathrm{pH}$ was adjusted by stock solutions (1-1 M) of $\mathrm{HCl}$ or $\mathrm{KOH}$.

Ficoll 400 is a highly branched polymer formed by the copolymerization of sucrose and epichlorohydrin. It is completely non-ionic, very hydrophilic, and extremely water soluble. Separations in Ficoll normally result in better preservation of cell function and morphology. We used different concentrations of Ficoll (1-10\%) to planktonic cells (Georgalis et al. 2012).

Carbonyl cyanide-4-(trifluoromethoxy)-phenylhydrazone (FCCP) is a widely used protonophore responsible for the collapse of the chemiosmotic membrane potential (Armitage 2001; Kelly and Thomas 2001), $20 \mu \mathrm{M}$ of which was added to the bacterial culture.

Nimodipine is a potent L-type $\mathrm{Ca}^{2+}$ channel antagonist (Ren et al. 2001). 10-100 $\mu \mathrm{M}$ was added to the samples.

Nitrendipine, as a $\mathrm{Ca}^{2+}$ channel blocker, was used in 50 $\mu \mathrm{M}$ concentration. The $\mathrm{Ca}^{2+}$ channel blockers had no effect on the growth of bacteria even when their concentrations were higher than those sufficient for the complete inhibition of $\mathrm{Ca}^{2+}$ uptake (Matsushita et al. 1988).

$\mathrm{N}$-Ethylmaleimide (N-Em) is a general sulfhydryl modifying agent used in $20 \mathrm{mM}$ concentration as described previously (Gao and Wraight 1990). It is an organic compound derived from maleic acid and contains the imide functional group. More importantly, N-Em is an alkene that is reactive toward thiols and is able to modify cysteine residues in proteins and peptides.

\section{Determination of $\mathrm{Hg}(\mathrm{II})$ with dithizone}

Dithizone (Diphenylthiocarbazone) as a chelating agent for metals was used to quantify the $\mathrm{Hg}^{2+}$ content of the bacterial culture. Similar method is applied to screen natural waters (lakes and rivers). The amount of $\mathrm{Hg}$ (II) in the aqueous solution of bacteria was determined by use of indirect spectrophotometric measurements of the $\mathrm{Hg}$ (II)-dithizone complex that has a high stability constant (Théraulaz and Thomas 1994). The dithizone was solubilized in absolute ethanol $\left(10^{-4} \mathrm{M}\right)$ using an ultrasonic bath. All solutions were prepared freshly before the experiment. In order to prevent oxidizing decomposition, the dithizone solution was kept in the dark at $<10^{\circ} \mathrm{C}$. Reagent solutions were added as $20 \mathrm{v} / \mathrm{v} \%$ dithizone solution and $80 \mathrm{v} / \mathrm{v} \%$ sample in distilled water $(\mathrm{pH} 3.1)$. The $\mathrm{pH}$ of the solutions was measured by a digital $\mathrm{pH}$ meter. The bacterial sample was prepared in the following way: the cells were centrifuged (8000 rpm, $5 \mathrm{~min}$ ) and then re-suspended in $10 \mathrm{mM} \mathrm{NaCl}$. All metals were removed from the medium; otherwise, they would form a complex with the dithizone and disturb the 
mercury assay. After the addition of $\mathrm{HgCl}_{2}$ to the bacterial culture, the cells were centrifuged. The supernatant contained the free (unbound) $\mathrm{Hg}$ (II) and the sedimented cells included the bound mercury $\left(\mathrm{Hg}_{\text {bound }}=\mathrm{Hg}_{\text {total }}-\mathrm{Hg}_{\text {free }}\right.$ ). The steady-state absorption spectra were recorded by a single-beam spectrophotometer (Thermo Spectronic Helios) in a $1 \times 1 \mathrm{~cm}$ quartz cuvette. Mercury(II)-dithizonate has an absorption band centered at around $480 \mathrm{~nm}$ and dithizone in acidic medium ( $\mathrm{pH}$ 3.1) shows absorption maximum at $585 \mathrm{~nm}$. The mercury concentrations were determined from the difference of the absorbances $(A)$ measured at $480 \mathrm{~nm}(\mathrm{Hg}$ (II)-dithizonate) and 585 (dithizone) $\mathrm{nm}$. The $R=\left(A_{585}-A_{480}\right) / A_{585}$ value measures the peak-valley difference to the maximum absorbance, is highly sensitive to the complexation of the mercury, and is calibrated by use of standard curves of $\mathrm{HgCl}_{2}$ solutions carried out before each measurement (Greenberg et al. 1992). The sensitivity and working range of the assay are $0.4 /\left(\mu \mathrm{g} \mathrm{Hg} \mathrm{L}^{-1}\right)$ and $2-100 \mu \mathrm{g} \mathrm{Hg} \mathrm{L}{ }^{-1}$, respectively.

\section{Steady-state absorption spectroscopy}

The steady-state near-infrared absorption spectra of the cells were recorded during the growth at room temperature by a single-beam spectrophotometer (Thermo Spectronic Helios). The baselines were corrected for light scattering.

\section{Flash-induced absorption kinetics}

The kinetics of absorption changes of the whole cells induced by Xe flash were detected by a home-constructed spectrophotometer (Maróti and Wraight 1988). The electrochromic band shift of the carotenoid pigments in the photosynthetic membrane was monitored at $530 \mathrm{~nm}$ with reference to $510 \mathrm{~nm}$ (Kis et al. 2014, 2015).

\section{Induction of BChl fluorescence}

The induction kinetics of the bacteriochlorophyll (BChl) $a$ fluorescence of intact cells were measured by a home-built fluorometer (Kocsis et al. 2010). The light source was a laser diode (808 $\mathrm{nm}$ wavelength and $2 \mathrm{~W}$ light power) that produced rectangular shape of illumination and matched the $800-\mathrm{nm}$ absorption band of the LH2 peripheral antenna of the cells. The BChl fluorescence (centered at $900 \mathrm{~nm}$ ) was detected in the direction perpendicular to the actinic light beam with a near-infrared-sensitive, large-area (diameter $10 \mathrm{~mm}$ ), and high-gain $\mathrm{Si}$-avalanche photodiode (APD; model 394-70-72-581; Advanced Photonix, Inc., USA) protected from the scattered light of the laser by an $850-\mathrm{nm}$ high-pass filter (RG-850).

\section{Results}

\section{Kinetics and activation energy of mercury uptake}

Photosynthetic bacteria take up mercury ions in two wellseparated kinetic steps as revealed by direct mercury determination assay (Fig. 1). The prompt (fast) uptake is very fast and the rise time cannot be resolved under our experimental conditions. This phase may reflect the adsorption

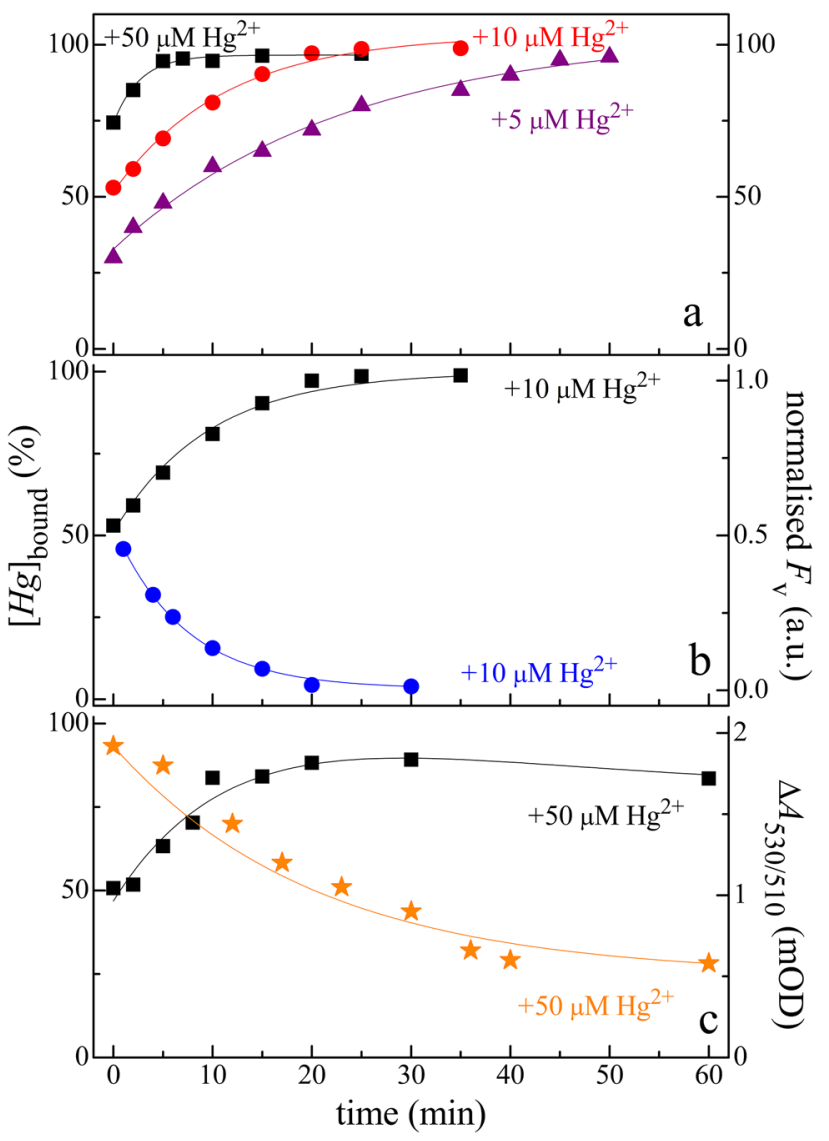

Fig. 1 Fast and slow phases of $\mathrm{Hg}(\mathrm{II})$ uptake ([Hg $]_{\text {bound }}$ ) by photosynthetic bacterium Rvx. gelatinosus (a) and its kinetic correlation with internal photosynthetic markers of variable part $\left(F_{\mathrm{v}}\right)$ of $\mathrm{BChl}$ fluorescence induction (b) and flash-induced absorption change ( $\Delta A_{530}$ vs. $\Delta A_{510}$ ) of the carotenoids in the photosynthetic membrane (c). After prompt addition of $\mathrm{Hg}$ (II) ions in the form of $\mathrm{HgCl}_{2}$, the amount of bound $\mathrm{Hg}$ (II) ions was determined by spectrophotometric dithizone assay at different time intervals. The cells of concentrations $1 \cdot 10^{6}(\mathbf{a}, \mathbf{b})$ and $1 \cdot 10^{8} \mathrm{cell} / \mathrm{ml}(\mathbf{c})$ were kept in the light during mercury treatment. a The rise time $\left(t_{1 / 2}\right)$ of the slow phase depends on the mercury concentration (filled square $50 \mu \mathrm{M} \mathrm{Hg}^{2+}, t_{1 / 2}=3 \mathrm{~min}$; filled circle $10 \mu \mathrm{M} \mathrm{Hg}^{2+}, t_{1 / 2}=11 \mathrm{~min}$; filled triangle $5 \mu \mathrm{M} \mathrm{Hg}^{2+}$, $\left.t_{1 / 2}=23 \mathrm{~min}\right)$. $\mathbf{b}$ The variable part of the induction of BChl fluorescence is referred to as the untreated case $\left(0 \mu \mathrm{M} \mathrm{Hg}^{2+}\right)$ and monitors the destruction of the photosynthetic apparatus due to $10 \mu \mathrm{M} \mathrm{Hg}^{2+}$. The halftimes are $7 \mathrm{~min}\left(F_{\mathrm{v}}\right.$, filled circle $)$ and $10 \mathrm{~min}\left([\mathrm{Hg}]_{\mathrm{bound}}\right.$, filled square). c Flash-induced energetization of the membrane reflects the drop of photosynthetic activity caused by $50 \mu \mathrm{M} \mathrm{Hg}^{2+}$. The halftimes are $17 \mathrm{~min}\left([\mathrm{Hg}]_{\text {bound }}\right.$, filled square $)$ and $20 \mathrm{~min}\left(\Delta A_{530 / 510}\right.$, filled star $)$ 
of $\mathrm{Hg}(\mathrm{II})$ ions to the cell surface groups and a passive and nonspecific diffusion through the cell membrane (leakage) driven primarily by the mercury concentration gradient. Additionally, we can observe a second and much slower kinetic phase that takes place in the minute time range and may be responsible for up to $2 / 3$ of the total mercury uptake. Both the magnitude and the rise time of the slow phase depend on the mercury concentration (Fig. 1a). The fast phase of the uptake is $[\mathrm{Hg}]$ dependent, since the vertical intercept of the graph increases with increasing $[\mathrm{Hg}]$. The larger is the $\mathrm{Hg}$ (II) concentration outside, the smaller are the partition (amplitude) and rise time $\left(t_{1 / 2}\right)$ of the slow component in mercury uptake. Upon increase of the external mercury concentration from 5 to $50 \mu \mathrm{M}, t_{1 / 2}$ decreases from 20 to $3 \mathrm{~min}$. The internal markers sensitive to photosynthetic activity give simultaneous signal about the invasion of $\mathrm{Hg}$ (II) ions into the cell and their subsequent destruction of the photosynthetic apparatus. In accordance with the slow entry of mercury ions detected by mercury assay, both the variable part of the induction of BChl fluorescence (Fig. 1b) and the electrochromic band shift of the carotenoids in the membrane (Fig. 1c) demonstrate decreasing kinetics from the level of the untreated $(0 \mu \mathrm{M}$ $\mathrm{Hg}^{2+}$ ) sample. The decay times of the internal photosynthetic reporters are commensurable with the half-rise times of the slow phase of mercury uptake.

The slow kinetic phase represents an energy-consuming transport mechanism because the magnitude of the uptake increases upon energetization of the membrane evoked by illumination (Fig. 2). If the photosynthetic bacterium is exposed to continuous light excitation, the amount of bound mercury ions enhances significantly compared to that when the bacteria are kept in the dark (Fig. 2a). The photochemical gradient assures additional energy supply for the active transport through the photosynthetic membrane. If, however, the illuminated cells are treated with FCCP, a well-known protonophore, the amplitude of the mercury saturation kinetics will drop to the level corresponding to the dark situation. As FCCP makes the membrane transparent for $\mathrm{H}^{+}$ions, the establishment of the photochemical (proton) gradient is blocked and the membrane cannot be energized.

Divalent cation transporters seem to contribute in side transport of mercury ions with low yield. Indeed, it can be observed from Fig. $2 b$ that $\mathrm{Ca}^{2+}$ channels may participate in mercury transport because the uptake of $\mathrm{Hg}$ (II) decreases significantly upon the addition of nimodipine (a potent L-type $\mathrm{Ca}^{2+}$ channel antagonist) and nitrendipine (a powerful $\mathrm{Ca}^{2+}$ channel blocker). In addition, the kinetics of slow saturation of the active uptake becomes substantially slower due to inhibition of the $\mathrm{Ca}^{2+}$ channels. The blockers did not affect the proton gradient and viability of the bacteria in the time and concentration

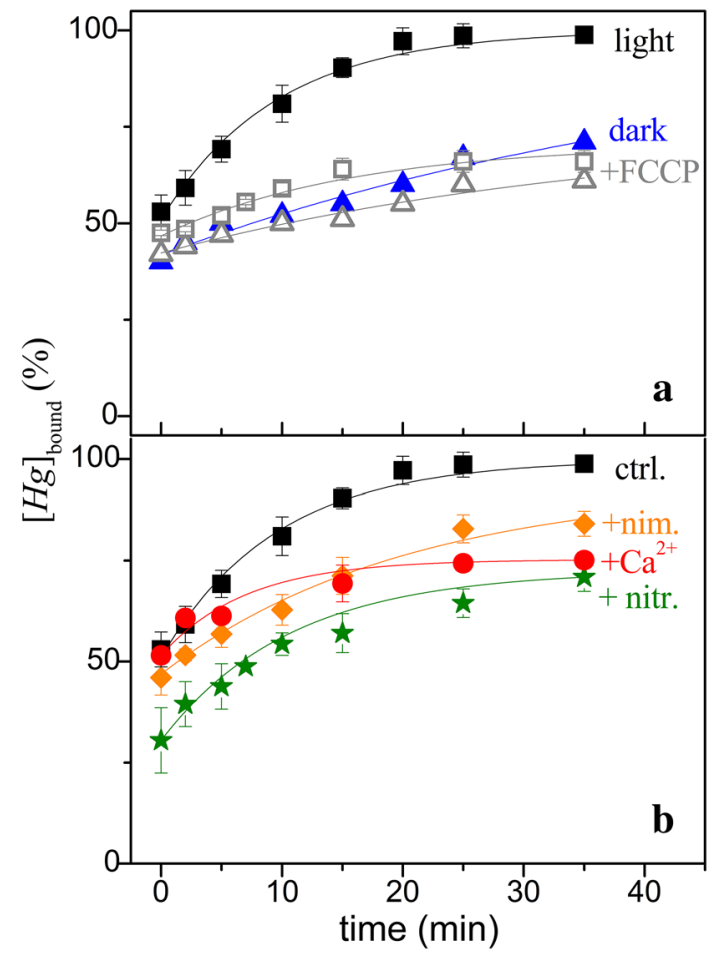

Fig. 2 Correlation of the slow mercury uptake with energetization of the membrane (panel $a$ ) and $\mathrm{Ca}^{2+}$ transport system in the light (panel $b$ ) in Rvx. gelatinosus. a Cells treated with $10 \mu \mathrm{M} \mathrm{Hg}^{2+}$ bind more mercury ions in the light (filled square) than in the dark (filled triangle) but not in the presence of $20 \mu \mathrm{M}$ FCCP in the dark (open triangle) and light (open square). $\mathbf{b} \mathrm{Ca}^{2+}$ channels may participate in mercury transport: the mercury uptake is diminished and decelerated relative to control (ctrl) upon the addition of nitrendipine, a $\mathrm{Ca}^{2+}$ channel blocker $(50 \mu \mathrm{M}$, filled star, nitr), nimodipine, a potent L-type $\mathrm{Ca}^{2+}$ channel antagonist $\left(50 \mu \mathrm{M}\right.$, filled diamond, nitr) or $\mathrm{Ca}^{2+}$ ions from the dissociation of $\mathrm{CaCl}_{2}\left(50 \mu \mathrm{M}\right.$, filled circle, $\left.\mathrm{Ca}^{2+}\right)$ in the light

ranges of treatment which affected the active uptake of Hg (see Figs. 2, 3; Matsushita et al. 1988). Similar inhibition of the active $\mathrm{Hg}^{2+}$ uptake can be induced by the presence of elevated $\mathrm{Ca}^{2+}$ ion concentration in the suspension. These results demonstrate that a considerable portion of mercuric transport through photosynthetic membrane should occur via $\mathrm{Ca}^{2+}$ channels.

The mode of action appears to differ with the two $\mathrm{Ca}$ uptake inhibitors tested, despite their target to similar $\mathrm{Ca}$ voltage-gated channels. Nimodipine stabilizes voltagegated calcium channel in its inactive conformation and therefore inhibits the influx of calcium in the cells (Goyer and Cherian 2012). Nimodipine appears to reduce $\mathrm{Hg}$ uptake but not affect binding to the surface. Nitrendipine, however, appears to have a more dramatic effect on $\mathrm{Hg}$ binding to the cell surface than uptake into the cell. Similarly, differences of modes of action between the two $\mathrm{Ca}$ antagonists were observed in single cardiac transmembrane Ca channels (Hess et al. 1984). 


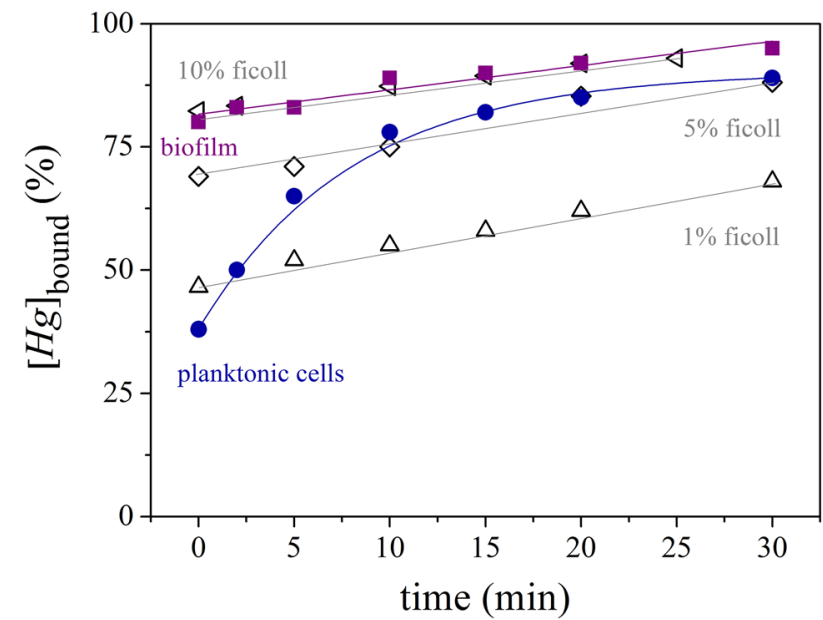

Fig. 3 Comparison of mercury uptake kinetics in planktonic cells of Rvx. gelatinosus (filled circle) and cells with natural biofilm (filled square) or with variable concentrations of Ficoll (open triangle 1\%, open diamond $5 \%$, and open left slanted triangle $10 \%$ ). The cell concentrations were kept the same in all cases $\left(1 \cdot 10^{8}\right.$ cell $\left./ \mathrm{mL}\right)$ and $50 \mu \mathrm{M}$ $\mathrm{Hg}^{2+}$ was added. The cells with polysaccharide Ficoll show similar mercury uptake kinetics as those with biofilm

The distinction between the diffusion and active steps of the mercury uptake is demonstrated not only kinetically but also by observed differences in activation energies. As the diffusion and active components of the mercury uptake from the bulk to the cell surface and from here to the interior of the cell are connected in series, the inverse of the observed rate $\left(k_{\text {obs }}\right)$ of uptake is the sum of the inverses of the diffusion $\left(k_{\mathrm{d}}\right)$ and active $\left(k_{\mathrm{a}}\right)$ rates: $\left(k_{\mathrm{obs}}\right)^{-1}=\left(k_{\mathrm{d}}\right)^{-1}$ $+\left(k_{\mathrm{a}}\right)^{-1}$. By measuring the observed rate, the activation energy of the rate-limiting step can be determined since this step must be responsible for the overall rate. Two extreme cases were sampled in our experiments of $\mathrm{Hg}$ (II) binding affinity of intact cells of Rvx. gelatinosus (Steunou et al. 2013). In the planktonic mode of living, the diffusion step is much faster than that through the membrane $\left(k_{\mathrm{d}}>>\right.$ $k_{\mathrm{a}}$ ). In biofilm mode, however, the cell is surrounded by an extensive network of dense extracellular polymeric matrix (consisting mainly of polysaccharides) where the diffusion of mercury ions to the cell surface becomes slower than the transport through the membrane.

The increase in the amount of the uptake by diffusion and the significant deceleration of the slow phase of the mercury ions by biofilm can be modeled if the planktonic cells are connected to an artificial network made of Ficoll 400 (Fig. 3). Ficoll does not have any adverse effects on viability of the bacteria and increases moreover the reproducibility of the biological sample by forming neutrally buoyant suspension (Turksen 2015). The network of polysaccharides (both of biofilm and Ficoll) decelerates the active and slow mercury uptake characteristic

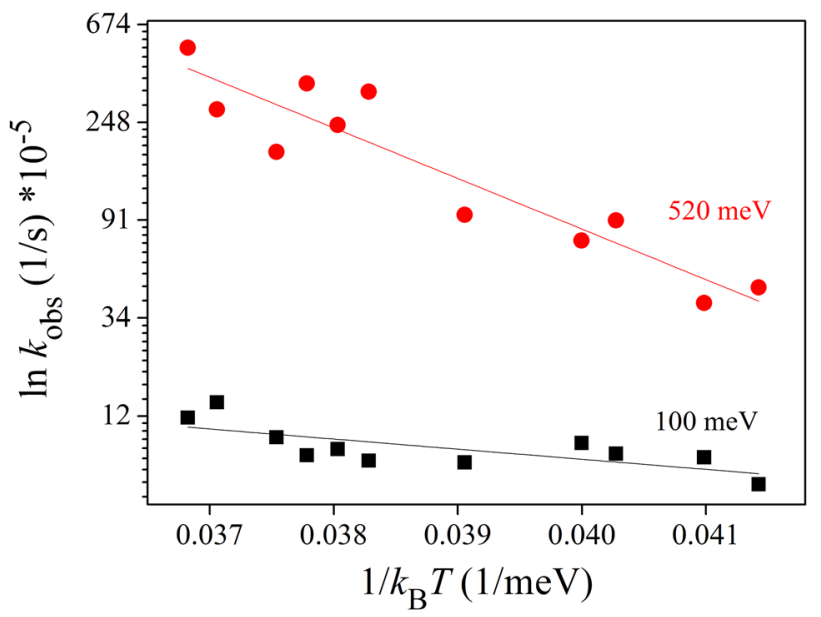

Fig. 4 Determination of activation energies of the mercury uptake of the planktonic (filled circle) and biofilm (filled square) modes of the bacterium Rvx. gelatinosus. The logarithm of the rate-limiting step (observed rate, $k_{\text {obs }}$ ) as a function of the inverse of the absolute temperature (Arrhenius plot) is approximated by a straight line whose slope is the activation energy: $520 \mathrm{meV}$ (planktonic cells) and $100 \mathrm{meV}$ (cells in biofilm). The conditions are the same as above

of planktonic bacteria so effectively that only the passive/fast phase is observable. Based on mercury saturation measurements, about $10 \%$ Ficoll is equivalent to biofilm of Rvx. gelatinosus, i.e., their mercury uptakes show similar kinetics. It should be emphasized that the chemical nature of the network, not the (about two times) increased viscosity, is responsible for the decreased mercury uptake.

The logarithm of the observed rate versus the inverse of the temperature (Arrhenius plot) gives two different straight lines for the planktonic and biofilm modes of the bacterium (Fig. 4). As expected, the planktonic cells show relatively large observed rate and steep slope that corresponds to $520 \mathrm{meV}$ activation energy. That energy is needed to transport the $\mathrm{Hg}$ (II) ions into the cell. This is a relatively large activation energy that can be covered by active metabolism of the cells in the early exponential phase of growth. While large, this energy can be achieved by the cell because it can manage this energy of activation in the bacterial RC where similarly large activation energy is required for the interquinone $\left(\mathrm{Q}_{\mathrm{A}}{ }^{-} \rightarrow \mathrm{Q}_{\mathrm{B}}\right)$ electron transfer (Milano et al. 2007). In biofilm mode of growth of the cell, however, the observed rate reduces substantially and the slope of the straight line also becomes small. An activation energy of $100 \mathrm{meV}$ can be derived which is characteristic of the diffusion-controlled processes whose small activation energy ( $80-200 \mathrm{meV}$ ) is ascribed to the temperature dependence of the viscosity. Our experiment is able to make a clear distinction between the activation energies of passive (diffusion) and active transport mechanisms. 
The slow kinetic phase of $\mathrm{Hg}(\mathrm{II})$ uptake saturation depends not only on the energetization of the membrane (Fig. 2) but on the $\mathrm{pH}$ of the solution, as well. After corrections for the effect of $\mathrm{pH}$ on viability of the bacteria, the dependence of the mercThe concentration of mercuryis given as the number of mercury atoms perury uptake on $\mathrm{pH}$ and time is demonstrated in the quasi-3D representation (Fig. 5). All pH profiles obtained from the plane sections parallel with the $\mathrm{pH}$ and time axes are highly similar: the mercury uptake has maximum at neutral $\mathrm{pH}$ and drops toward both the acidic and alkaline $\mathrm{pH}$ ranges. However, the decline is more pronounced at low $\mathrm{pH}$ than at high $\mathrm{pH}$ values. The two shaded planes represent the mercury uptake in dark and light states of the photosynthetic bacteria. The light state is characterized by light-generated proton motive force, i.e., the photosynthetic membrane is energized $(\sim 100 \mathrm{meV})$ compared to that of the dark state. Because the two planes do not show much (if any) differences, the light-induced energetization of the photosynthetic membrane should not affect the $\mathrm{pH}$ dependence of the mercury uptake. Instead, the competition of $\mathrm{Hg}^{2+}$ ions with $\mathrm{H}^{+}$(low-pH) or $\mathrm{OH}^{-}$(high-pH) ions will determine the shape of the $\mathrm{pH}$ dependence. The drops at $\mathrm{pH}$ values far from $\mathrm{pH} 7$ are attributed to these competitions and not to (possible) changes of the light-generated proton motive force.

The formation of mercuric oxide, a toxic yellow precipitate, via $\mathrm{HgCl}_{2}+2 \cdot \mathrm{OH}^{-} \rightarrow \mathrm{HgO}+\mathrm{H}_{2} \mathrm{O}+2 \cdot \mathrm{Cl}^{-}$should have

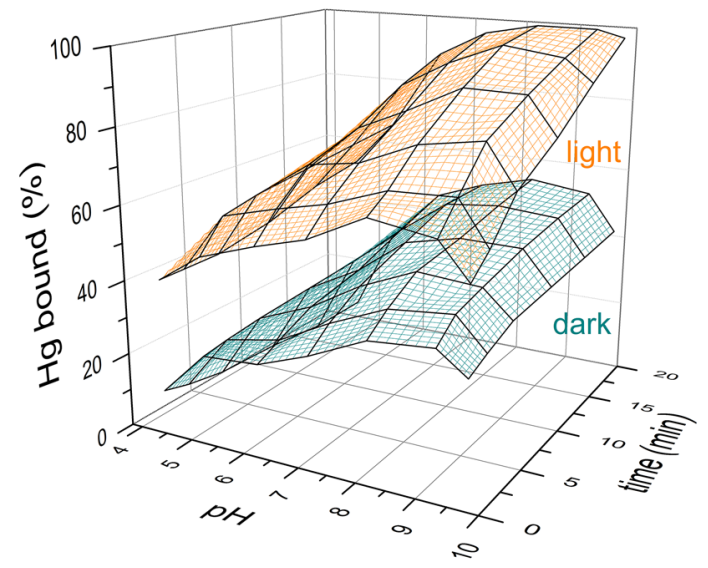

Fig. 5 Quasi-3D representation of the mercury uptake of Rvx. gelatinosus in the dark (lower surface) and under illumination (upper surface) as the functions of the duration of mercury treatment and $\mathrm{pH}$ of the culture. At all times and independently on the dark/light conditions, the mercury uptake has maximum at neutral $\mathrm{pH}$ and drops in the acidic and alkaline $\mathrm{pH}$ ranges. The view from this angle shows clearly the asymmetric $\mathrm{pH}$ behavior: the uptake is highly sensitive at the low (acidic) pH but less sensitive at the high (alkaline) pH. The datasets are corrected for the $\mathrm{pH}$ dependence of the vitality (survival) of the bacteria and for the loss of $\mathrm{Hg}^{2+}$ due to $\mathrm{HgO}$ production in the alkaline $\mathrm{pH}$ range also been taken into account as the loss of $\mathrm{HgCl}_{2}$ and toxic agent for bacteria in the culture in the alkaline $\mathrm{pH}$ range. $\mathrm{HgO}$ can bioaccumulate in the food chain, specifically in aquatic organisms (Greenwood and Earnshaw 1997). As mercuric oxide appears as a yellow precipitate in the culture, it increases light scattering in a pH-dependent manner. The larger is the amount of mercuric oxide, the higher is the turbidity of the suspension. By combination of the light scattering measurement with the dithizone $\mathrm{Hg}^{2+}$ assay, the amount of $\mathrm{HgO}$ produced and the loss of $\mathrm{Hg}^{2+}$ in the culture could be derived. At $\mathrm{pH} 10$, about $20 \%$ of dissolved mercury is converted to $\mathrm{HgO}$ precipitate.

\section{Multiple binding equilibria of mercury ions by cell}

As the intact cell $(\mathrm{C})$ has a very large number of binding sites for interaction with small mercury ions $(\mathrm{Hg})$, a relatively large mercury concentration $([\mathrm{Hg}] \sim 1 \mathrm{mM})$ is needed to saturate $\mathrm{Hg}$ binding in a dilute suspension of cells $\left([\mathrm{C}] \sim 1 \times 10^{5}\right.$ cell $/ \mathrm{mL}$ ) (Fig. 6). At significantly higher cell concentrations,

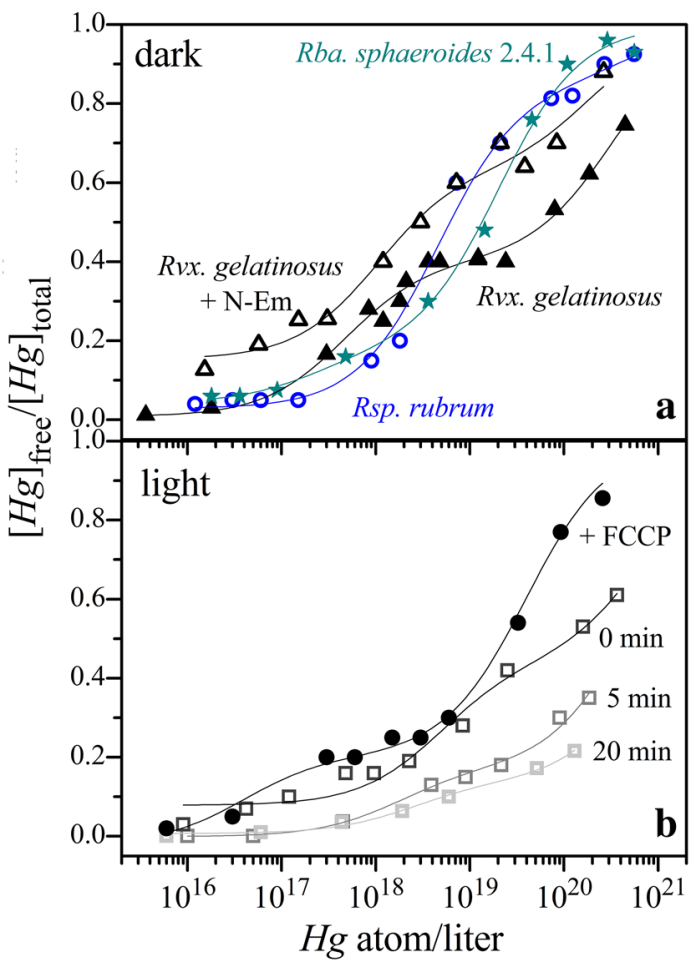

Fig. 6 Saturation curves of mercury uptake for different bacterial strains under dark (a) and light (b) conditions. a Rsp. rubrum (open circle), Rvx. gelatinosus (filled triangle), Rvx. gelatinosus $+20 \mathrm{mM}$ N-Em (open triangle), and Rba. sphaeroides (filled star). b Rvx. gelatinosus illuminated for $0 \mathrm{~min}$ (open square, dark gray), $5 \mathrm{~min}$ (open square, gray), and 20 min (open square, light gray and +20 $\mu \mathrm{M}$ FCCP (filled circle, dark gray)). The concentration of mercury is given as the number of mercury atoms per liter. The solid lines through the measured data are the least square best fits of Eq. (4) (see Table 1 for the parameters) 
Table 1 Number of binding sites $(n)$ and binding constants $(K)$ for weak and strong binding of mercury to different bacterial strains under various conditions (treatment with chemicals, illumination, and time delay after mercury addition)

\begin{tabular}{lllll}
\hline \multicolumn{4}{l}{ Fitting parameters } \\
\cline { 2 - 4 } & $n_{\mathrm{s}}\left(\times 10^{9}\right)$ & $n_{\mathrm{w}}\left(\times 10^{12}\right)$ & $K_{\mathrm{s}}(\mu \mathrm{M})^{-1}$ & $K_{\mathrm{w}}(\mathrm{mM})^{-1}$ \\
\hline Species & & & & \\
Rsp. rubrum & 7.6 & 0.16 & 0.13 & 1 \\
Rba. sphaeroides & 0.06 & 0.03 & 2.8 & 30 \\
Rvx. gelatinosus & 0.4 & 0.4 & 1.25 & 2 \\
Chemicals & & & & \\
Dark & & & & \\
$\quad$ Nimodipine & 0.7 & 0.3 & 0.4 & 2.7 \\
$\quad$ n-Em & 0 & 0.03 & 0 & 26 \\
Light & & & & \\
Nimodipine & 1 & 0.4 & 0.4 & 1.6 \\
FCCP & 0.03 & 0.07 & 9 & 13 \\
Time & & & & \\
0 min & 3.5 & 0.9 & 0.12 & 0.8 \\
5 min & 0.6 & 1 & 0.34 & 1 \\
20 min & 0.7 & 2 & 0.24 & 0.5 \\
\hline
\end{tabular}

The parameters were derived by least square fitting of the mercury saturation curves (see, e.g., Fig. 6) by Eq. (4)

Table 2 Comparison of the mercury binding capacities $(n \cdot K \cdot[C])$ of highly concentrated cultures of photosynthetic bacteria $\left([\mathrm{C}]=1 \times 10^{13} \mathrm{cell} / \mathrm{L}\right)$ based on the measurement of the initial limiting value of mercury saturation curves [see Eq. (5)]

\begin{tabular}{llll}
\hline Strain & $\lim ^{[\mathrm{Hg}]_{\text {total }} \rightarrow 0} \frac{[\mathrm{Hg}]_{\text {free }}}{[\mathrm{Hg}]_{\text {total }}}$ & & \multicolumn{2}{l}{$n \cdot K \cdot[\mathrm{C}]$} & \\
\cline { 3 - 4 } & & $\mathrm{abs}$ & rel \\
\hline $\begin{array}{l}\text { Rba. sphaeroides 2.4.1 } \\
\text { Rvx. gelatinosus }\end{array}$ & 0.18 & 4.5 & 1.0 \\
Planktonic & & & \\
Biofilm & 0.10 & 9.0 & 2.0 \\
\hline
\end{tabular}

Notations abs and rel mean the absolute and relative values of $n \cdot K \cdot[C]$, respectively

the cells tend to aggregate and the analysis becomes more difficult as the linearity is lost. For short exposure of the cell to $\sim 1 \mathrm{mM} \mathrm{Hg}$ concentration, saturation can be reached without destruction of the cell. After proper analysis, the binding constants of mercury ion to the cell $(K)$, the numbers of binding sites $(n)$ and occupied binding sites $(\nu)$ in a single cell, and cooperativity of the binding sites can be derived from the shape of the measured saturation curve. The number of occupied binding sites on the cell can be expressed as

$v=\frac{[H g]_{\text {total }}-[H g]_{\text {free }}}{[C]}$, where $[\mathrm{Hg}]_{\text {total }}$ and $[\mathrm{Hg}]_{\text {free }}$ denote the concentrations of total and free (=total-bound) $\mathrm{Hg}$ ions, respectively. In the simplest case of identical and independent binding sites,

$v=\frac{n \cdot K \cdot[H g]_{\text {free }}}{1+K \cdot[H g]_{\text {free }}}$.

If the cell possesses groups of two different (weak and strong) binding sites of binding constants $K_{\mathrm{w}}$ (weak) and $K_{\mathrm{s}}$ (strong) and $n_{\mathrm{w}}$ and $n_{\mathrm{s}}$ number of sites, respectively, and the cooperativity among the binding sites may be neglected, then the occupation numbers can be added:

$\nu=\frac{n_{w} \cdot K_{w} \cdot[H g]_{\text {free }}}{1+K_{w} \cdot[H g]_{\text {free }}}+\frac{n_{s} \cdot K_{s} \cdot[H g]_{\text {free }}}{1+K_{s} \cdot[H g]_{\text {free }}}$.

Combining Eqs. (1) and (3), one can express the experimentally measured $[\mathrm{Hg}]_{\text {free }} /[\mathrm{Hg}]_{\text {total }}$ ratio as a function of the free $\mathrm{Hg}$ concentration:

$\frac{[\mathrm{Hg}]_{\text {free }}}{[\mathrm{Hg}]_{\text {total }}}=1-\frac{n_{w} \cdot K_{w} \cdot[\mathrm{C}]}{1+K_{w} \cdot[\mathrm{Hg}]_{\text {free }}}-\frac{n_{s} \cdot K_{s} \cdot[\mathrm{C}]}{1+K_{s} \cdot[\mathrm{Hg}]_{\text {free }}}$.

As the binding constants differ greatly (by two orders of magnitude, at least), the analysis of the binding situation is not so difficult in our case. The results of decomposition of the experimentally obtained saturation curves into two components according to Eq. (4) for different bacterial strains and conditions are summarized in Table I. From the large number of binding sites, one can see that photosynthetic bacteria serve as a sponge of mercury ions as they can accumulate $\mathrm{Hg}(\mathrm{II})$ in amounts much (at least $10^{5}$ times) greater than their own masses.

If the concentration of the cells is too large $\left([\mathrm{C}]>>1 \cdot 10^{6}\right.$ cells $/ \mathrm{mL}$ ), the actual mercury concentration will far not saturate the bacteria; therefore, the parameters of $\mathrm{Hg}$ (II) binding cannot be obtained in that way. Instead of the analysis of the whole saturation curve, the determination of the initial value can be used to compare the mercury binding capacities of different bacteria. The limiting value is

$\lim _{[H g]_{\text {total }} \rightarrow 0} \frac{[H g]_{\text {free }}}{[H g]_{\text {total }}}=\frac{1}{1+n \cdot K \cdot[C]}$,

where $n$ and $K$ refer to the number of binding sites and the equilibrium binding constant of the strongest binding, respectively. The product $n \cdot K \cdot[C]$ measures the mercury binding capacity of the bacterial culture. Adjusting the same cell concentration $\left([\mathrm{C}]=1 \times 10^{13}\right.$ cell/L) for different highly concentrated samples, their mercury binding capacities can be compared (Table 2). Rba. sphaeroides has twice less capacity than $R v x$. gelatinosus in planktonic mode that has five times less capacity than in biofilm mode. The 
increase in the latter case may be attributed to the mercury binding of the biofilm.

\section{Discussion}

The discussion will focus on four aspects of mercury accumulation in intact photosynthetic bacteria.

\section{Kinetics and mechanisms of mercury binding/uptake}

Based on Hg assay, we could clearly decompose the kinetics of mercury uptake into two (fast and slow) components. The fast phase includes (a) biosorption of mercury ions to extracellular cell surface-associated polysaccharides and proteins and (b) passive diffusion through the membrane. The passive uptake is rapid, reversible, relatively nonspecific with respect to the metal species and independent of cellular metabolisms (enzymatic processes) and physical conditions such as $\mathrm{pH}$ and ionic strength. It is defined as an attribute of the inactive or dead microbial biomass to bind and concentrate mercury ions even from highly dilute solutions. The comparatively slow kinetic phase, however, reflects active processes and depends on the cellular metabolism as seen from decreased rate observed with protonophore (Fig. 2). The mercury(II) ions may utilize various energy-dependent transport systems including ion pumps, ion channels, and carrier-mediated transport.

Potentially toxic metals could be transported across the membrane via the channel (pump) of essential ions (Langston and Bebianno 1998). Calcium provides the most common divalent cationic channel and is the most likely route for entry of a number of metal pollutants including mercury. We demonstrated that $\mathrm{Hg}$ (II) ion influx across the bacterial membranes was affected by $\mathrm{Ca}$ channel blockers such as nimodipine (Hinkle et al. 1987) and nitrendipine (Barton 2005), which indicates the involvement of $\mathrm{Ca}$ channels in the mercury transport process: it is associated with and competed by the transport of $\mathrm{Ca}^{2+}$ ions (Fig. 2). This finding is in accordance with the observation of decreased $\mathrm{Hg}^{2+}$ accumulation by gram-negative bioreporter upon increasing divalent cation $\left(\mathrm{Ca}^{2+}\right)$ concentrations (Daguené et al. 2012). The authors proposed that divalent cations contributed to hampering net $\mathrm{Hg}^{2+}$ accumulation by decreasing outer membrane permeability and, therefore, the passive diffusion of $\mathrm{Hg}^{2+}$ species to the periplasmic space.

We were able to separate the passive and active modes of mercury uptake based not only on kinetics but also on activation energy. While the passive uptake has low activation energy $(\sim 100 \mathrm{meV})$ in accordance with our hypothesized diffusion mechanism, the active transport requires much (about 5 times) larger activation energy $(\sim 500 \mathrm{meV})$. We could model this switch between the rate-limiting steps by changing the condition of cultivation for bacterium $R v x$. gelatinosus. In the early exponential phase of growth, the cells of this strain are planktonic. The dissolved mercury is readily available to the cells and therefore its rate of diffusion will not limit the kinetics of the $\mathrm{Hg}$ uptake. In the late stationary phase of growth, however, the cells become incorporated in biofilm and the diffusion of mercury to the cell surface through the biofilm becomes the bottleneck of the rate of $\mathrm{Hg}$ uptake.

\section{The mercury uptake is $\mathrm{pH}$ dependent}

The $\mathrm{pH}$ dependence of mercury accumulation is a diverse field of research with many particular observations and results that are difficult to treat comprehensively (Kelly et al. 2003; Le Faucheur et al. 2011; Italiano et al. 2009). Here, we observed pH-dependent bioaccumulation of mercury with the largest value in the neutral $\mathrm{pH}$ range and decreased substantially upon acidification and alkalization of the solution. Kelly et al. (2003) reported an opposite $\mathrm{pH}$ tendency by an aquatic bacterium in a narrow $(6.3<\mathrm{pH}<7.3)$ range. Le Faucheur et al. (2011) have examined the influence of $\mathrm{pH}$ on $\mathrm{Hg}$ (II) uptake (mainly in the form of the lipophilic complex $\mathrm{HgCl}_{2}$ ) by the green, unicellular alga, Chlamydomonas reinhardtii and observed that the uptake of the dichloro complex increased by a factor of 1.6-2 when the $\mathrm{pH}$ was lowered from 6.5 to 5.5. Several mechanisms were explored to explain the enhanced uptake at $\mathrm{pH} 5.5$, including $\mathrm{pH}$-induced changes in cell surface binding of $\mathrm{Hg}$ or in $\mathrm{Hg}$ loss rates from cells, but none of them gave completely satisfactory explanations. Their findings imply that inorganic $\mathrm{Hg}$ (II) in aqueous solution behaves, in terms of uptake, neither as a lipophilic complex (the uptake of which would be expected to decrease with acidification because of algal membrane packing), nor as a cationic metal (the transport of which by facilitated transport would be expected to diminish with increasing proton concentration because of metal-proton competition at the transporter binding sites). In their experiment, mercury uptake by algae seems rather to be stimulated rather inhibited by proton addition.

In this work, we demonstrated an inverse relationship of the mercury uptake to the concentration of $\mathrm{H}^{+}$in the acidic $\mathrm{pH}$ range that cannot be explained by the assumption of simple diffusion of neutrally charged species $\mathrm{HgCl}_{2}$ to the bacterium but rather of a $\mathrm{pH}$-dependent facilitated mechanism by which $\mathrm{Hg}(\mathrm{II})$ is taken up by the cells in competition with $\mathrm{H}^{+}$ions or by $\mathrm{H}^{+} / \mathrm{Hg}^{2+}$ antiport. The simplest explanation is based on the competitive binding of $\mathrm{Hg}^{2+}$ ions to the diverse protonatable sites of the surface groups. The lower is the $\mathrm{pH}$, the larger is the fraction of the protonated residues (see Maróti and Wraight 1988 for RC) and the smaller is the amount of bound mercury ions 
to the protonatable sites. According to our view, deprotonated forms of protonatable residues covering the acidic $\mathrm{pH}$ range can be made responsible for mercury immobilization (Italiano et al. 2009).

The similar $\mathrm{pH}$ behavior observed at the alkaline $\mathrm{pH}$ range needs different explanation than $\mathrm{Hg}^{2+}$ competition with $\mathrm{H}^{+}$ions. Mercury hydroxo-complexes available to cells seem to be important for the accumulation on cell surface and for permeabilization of the cell membrane and can play a determining role in $\mathrm{pH}$ dependence of the mercury uptake. As demonstrated in our light scattering experiments, hydroxyl complexes tend to precipitate in the aqueous solution with two consequences, at least: (1) more and more alkaline solution will contain less and less active mercuric(II) ion for uptake; (2) the produced toxic forms of mercuric compounds (e.g., $\mathrm{HgO}$ ) will start to destroy the cell. These processes will contribute to the observed drop of the mercury uptake in the alkaline $\mathrm{pH}$ range.

The view of $\mathrm{pH}$-induced changes in bacterial mercury uptake is further supported by the experimental observation that the $\mathrm{pH}$ profile established by the initial equilibrium of binding/unbinding at the cell surface is not modified essentially upon energetization of the cell membrane (see Fig. 5). Only the magnitude of the mercury uptake and not the shape of the $\mathrm{pH}$ dependence changed significantly, when the membrane was energetized by light excitation.

Discussing the $\mathrm{pH}$ dependence of mercury uptake by photosynthetic bacteria, the suboptimal metabolic rate for different $\mathrm{pH}$ values should not be glossed over because the importance of metabolism on $\mathrm{Hg}$ uptake was shown in this work. Most enzymes typically have optimal $\mathrm{pH}$ range between $\mathrm{pH} 3$ and 8 that leads to a very complicated $\mathrm{pH}$ dependence of the bacterial metabolism. In an attempt to provide a full description of the observed $\mathrm{pH}$ dependence of the mercury uptake, the possible change of the metabolic rate should also be considered.

\section{Hill plot of mercury uptake}

After introducing the degree of saturation of the binding sites $(\Theta=v / n)$, the Hill plot can be constructed by graphing $\log \frac{\Theta}{1-\Theta}$ versus $\log [H g]_{\text {free }}$ on the basis of Eq. (2) (Fig. 7). This representation can demonstrate the difference between independent and cooperative binding sites at the cost of losing information for $n_{\mathrm{w}}$ and $n_{\mathrm{s}}$, the numbers of binding sites of different affinities of the cell. On a wide range of mercury concentrations, two straight lines with slopes of 1 were found indicating no cooperation of the binding sites. It is a remarkable experimental conclusion that despite the large number of binding sites and their large affinity of mercury ions, the binding sites are independent, i.e., their binding status does not influence the binding properties of the neighbors. The binding constants of the weak and

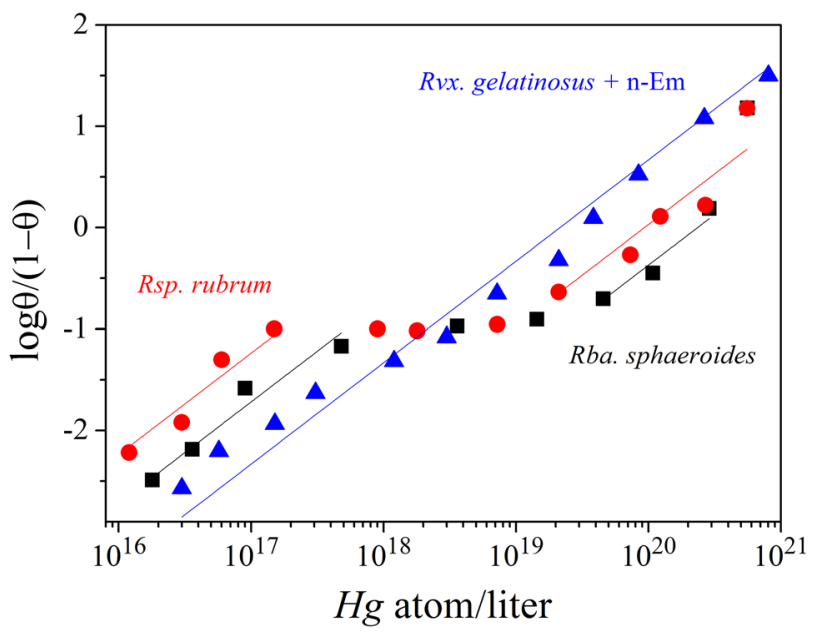

Fig. 7 Hill plots of the mercury uptake of three different strains of photosynthetic bacteria Rsp. rubrum (filled circle), Rba. sphaeroides (filled square), and Rvx. gelatinosus [with $20 \mathrm{mM}$ sulfhydryl modifying agent $\mathrm{N}$-ethylmaleimide (n-Em)] (filled triangle). Note the unity slopes (no cooperativity among the binding sites] and the two (weak and strong) binding sites except the presence of sulfhydryl modifier

strong binding sites can be obtained from the inverse values of the interceptions of the straight lines with the horizontal line through the half saturation value $\left(\Theta=1 / 2, \log \frac{\Theta}{1-\Theta}=0\right)$. The strong binding sites of the cell can be associated with sulfhydryl groups as the use of N-ethylmaleimide, a general sulfhydryl modifying agent, eliminates the straight line representing the sites of high mercury affinity. One could expect cooperativity among the strong binding sites but it is also unimportant as relatively few strong binding sites are available (two-three orders of magnitude less than that of the weak binding sites; see Table 1) and their interaction can be neglected.

\section{Biofilm protects the cell against mercury toxicity}

Many bacteria are embedded in an extracellular polymeric substance matrix composed of polysaccharides, proteins, and nucleic acids (Flemming and Wingender 2001). The surface-attached communities (biofilms) increase resistance to antimicrobial agents compared to the resistance of freeswimming organisms (Hentzer et al. 2001) probably due to decreased metabolic activity within the depths of a biofilm (Spoering and Lewis 2001) and to binding and sequestration of antimicrobial agents by biofilm components, such as negatively charged phosphate, sulfate, and carboxylic acid groups (Hunt 1986). As biofilms facilitate sorption of heavy metals, they are capable of removing heavy metal ions from bulk liquid (Liehr et al. 1994; Labrenz et al. 2000).

We observed that photosynthetic bacteria Rvx. gelatinosus with biofilms were more resistant to $\mathrm{Hg}^{2+}$ than 
planktonic cells (without biofilms). The effect can be attributed to the decrease of the dissolved mercury concentration because of the adsorption of the mercury species to the biofilms. The upload of the mercury pools of the cells and the biofilm is a competitive process. Another possible explanation for increased resistance to mercury in biofilms is that the negatively charged extracellular polysaccharides can effectively bind $\mathrm{Hg}^{2+}$ from the bulk solution (Teitzel and Parsek 2003). This view is further supported by our experiment where the natural biofilm is replaced by a similar artificial polysaccharide network produced by Ficoll. Because of the abundance of hydroxyl groups, Ficoll 400 is very hydrophilic and extremely water soluble. Addition of Ficoll to the planktonic cells increases the passive mercury uptake to a similar level as observed in cells in biofilm mode. This is in contrast to the finding in the Gram-negative bacterium Escherichia coli 055 where Najera et al. (2005) observed that the presence of the biofilm did not drastically change the relative availability of the dominant mercury species including the neutral $\mathrm{HgCl}_{2}$ species dominating under our conditions.

The mercury uptake measurements have been conducted mainly with batch planktonic cultures, for which the uptake of mercury species involves diffusion across an aqueous unstirred layer to the cell surface and further through the lipid bilayer cell membrane into the cell interior. However, it is now well established that the majority of bacteria in the environment live in attached communities or biofilms. Our model photosynthetic bacterium Rvx. gelatinosus is able to evolve biofilm during the growth and is expected to affect mercury availability (and its more harmful methylation) in several ways, including (1) changes in mercury speciation with steep chemical gradients within the biofilm, (2) the formation of an additional diffusive layer surrounding cells, and (3) adsorption of mercury by the biofilm. Although the photosynthetic bacterium Rvx. gelatinosus is unable to methylate mercury, the evolved network can colonize numerous other organisms (primarily sulfate- and iron-reducing bacteria and methanogens in anaerobic sediments of aquatic systems) with the capacity of methylation of $\mathrm{Hg}^{2+}$. In this way, the biofilm offers stage for link between the anoxygenic phototrophs and methylators and the understanding of mercury uptake by anoxygenic phototrophs is critical from the perspective of the methylators. These organisms thrive at similar redox interfaces in the environment so there needs to be some context for what $\mathrm{Hg}$ uptake by phototrophs means for $\mathrm{Hg}$ availability to methylators and how this affects the substrate available for methylation.

Our findings shed some light on the importance of $\mathrm{Hg}$ availability in anoxic environments and on several potential implications for mercury cycling, including effects on elemental mercury production, mercury sedimentation, and microbial methylation of $\mathrm{Hg}$ (II). In a more global perspective, the present study could be part of the explanation for many environmental hazards, including among others the observed connection between lake acidity and increased (methyl) mercury levels in fish (Mailman et al. 2006; Hongve et al. 2012) and the effects of primary physical-chemical factors on the harmful $\mathrm{Hg}$ uptake and methylation in the food webs.

Acknowledgements We are grateful to Prof. James Smart, University of Tennessee, Martin, USA, for discussions and careful reading of the manuscript. Thanks to COST (CM1306), GINOP-2.3.2-15-201600001, OTKA-K 112688, and EFOP -3.6.2-16 for financial support.

\section{References}

Abdia O, Kazemia M. (2015) A review study of biosorption of heavy metals and comparison between different biosorbents. J Mater Environ Sci 6(5):1386-1399

Ahluwalia SS, Goyal D (2007) Microbial and plant derived biomass for removal of heavy metals from wastewater. Bioresour Technol 98(12):2243-2257

Armitage JP (2001) Light responses in purple photosynthetic bacteria. Compr Ser Photosci 1:117-150

Asztalos E, Italiano F, Milano F, Maróti P, Trotta M (2010) Early detection of mercury contamination by fluorescence induction of photosynthetic bacteria. Photochem Photobiol Sci 9:1218-1223

Asztalos E, Sipka G, Kis M, Trotta M, Maróti P (2012) The reaction center is the sensitive target of the mercury(II) ion in intact cells of photosynthetic bacteria. Photosynth Res 112(2):129-140

Bae W, Mehra RK, Mulchandani A, Chen W (2001) Genetic Engineering of Escherichia coli for Enhanced Uptake and Bioaccumulation of Mercury. Appl Environ Microbiol 67(11):5335-5338

Bakkaloglu I, Butter TJ, Evison LM, Holland FS, Hancock IC (1998) Screening of various types biomass for removal and recovery of heavy metals $(\mathrm{Zn}, \mathrm{Cu}, \mathrm{Ni})$ by biosorption, sedimentation and desorption. Water Sci Technol 38:269-277

Barton L (2005) Structural and Functional Relationships in Prokaryotes. Springer Science \& Business Media, Berlin

Chang JS, Law R, Chang CC (1997) Biosorption of lead, copper and cadmium by biomass of Pseudomonas aeruginosa PU21. Water Res 31:1651-1658

Daguené V, McFall E, Yumvihoze E, Shurong X, Amyot M (2012) Divalent base cations hamper HgII uptake. Environ Sci Technol 46:6645-6653

Deng X, Jia P (2011) Construction and characterization of a photosynthetic bacterium genetically engineered for $\mathrm{Hg}^{2+}$ uptake. Bioresour Technol 102:3083-3088

Deng X, Wang P (2012) Isolation of marine bacteria highly resistant to mercury and their bioaccumulation process. Bioresour Technol 121:342-347

Flemming H-C, Wingender J (2001) Relevance of microbial extracellular polymeric substances (EPSs). Part I. Structural and ecological aspects. Water Sci Technol 43:1-8

Gabr RM, Hassan SHA, Shoreit AAM (2008) Biosorption of lead and nickel by living and non-living cells of Pseudomonas aeruginosa ASU 6a. Int Biodeterior Biodegradation 62:195-203

Gao J-L, Wraight CA (1990) Sulfhydryl modifying reagents inhibit $\mathrm{Q}_{\mathrm{A}}{ }^{-}$oxidation in reaction centers from Rhodobacter sphaeroides and Capsulatus, but not Rhodopseudomonas viridis. Photosynth Res 26(3):171-179 
Georgalis Y, Philipp M, Aleksandrova R, Krüger JK (2012) Light scattering studies on Ficoll PM70 solutions reveal two distinct diffusive modes. J Colloid Interface Sci 386(1):141-147

Giotta L, Agostiano A, Italiano F, Milano F, Trotta M (2006) Heavy metal ion influence on the photosynthetic growth of Rhodobacter sphaeroides. Chemosphere 62:1490-1499

Glick BR (2010) Using soil bacteria to facilitate phytoremediation. Biotechnol Adv 28:367-374

Gourdon R, Bhende S, Rus E, Sofer SS (1990) Comparison of cadmium biosorption by Gram-positive and Gram-negative bacteria from activated sludge. Biotechnol Lett 12:839-842

Goyer RA, Cherian MG (2012) Toxicology of metals: biochemical aspects. Springer Science \& Business Media, Berlin

Greenberg AE, Clesceri LS, Eaton AD (1992) Standard methods for the examination of water and wastewater, 18th edition. A.P.H.A., Washington

Greenwood NN, Earnshaw A (1997) Chemistry of the elements, 2nd edn. Butterworth-Heinemann, Oxford

Grégoire D, Poulain AJ (2014) A little bit of light goes a long way: the role of phototrophs on mercury cycling. Metallomics 6(3):396-407

Gregoire DS, Poulain AJ (2016) A physiological role for $\mathrm{Hg}(\mathrm{II})$ during phototrophic growth. Nat Geosci 9(2):121-125

Hentzer M, Teitzel GM, Balzer GJ, Heydorn A, Molin S, Givskov M, Parsek MR (2001) Alginate overproduction affects Pseudomonas aeruginosa biofilm structure and function. $\mathrm{J}$ Bacteriol 183:5395-5401

Hess P, Lansman JB, Tsien RW (1984) Different modes of Ca channel gating behaviour favoured by dihydropyridine $\mathrm{Ca}$ agonists and antagonists. Nature 311:538-544

Hinkle PM, Kinsella PA, Osterhoudt KC (1987) Cadmium uptake and toxicity via voltage-sensitive calcium channels. J Biol Chem 262(34):16333-16337

Hongve D, Haaland S, Riise G, Blakar I, Norton S (2012) Decline of acid rain enhances mercury concentrations in fish. Environ Sci Technol 46(5):2490-2491

Hunt S (1986) Diversity of biopolymer structure and its potential for ionbinding applications. In: Eccles H, Hunt S (eds) Immobilisation of ions by bio-sorption. Ellis Horwood Ltd., West Sussex, pp 15-46

Italiano F, Buccolieri A, Giotta L, Agostiano A, Valli L, Milano F, Trotta M (2009) Response of the carotenoids mutant Rhodobacter sphaeroides growing cells to cobalt and nickel exposure. Int Biodeterior Biodegr 63(7):948-957

Kane AL, Al-Shayeb B, Holec PV, Rajan S, Le Mieux NE, Heinsch SC, Psarska S, Aukema KG, Sarkar CA, Nater EA, Gralnick JA (2016) Toward bioremediation of methylmercury using silica encapsulated Escherichia coli harboring the mer operon. PLoS ONE 11(1): e0147036. doi:10.1371/journal.pone.0147036

Kelly DJ, Thomas GH (2001) The tripartite ATP-independent periplasmic (TRAP) transporters of bacteria and archaea. FEMS Microbiol Rev 25(4):405-424

Kelly CA, Rudd JW, Holoka MH (2003) Effect of pH on mercury uptake by an aquatic bacterium: implications for $\mathrm{Hg}$ cycling. Environ Sci Technol 37(13):2941-2946

Kis M, Asztalos E, Sipka G, Maróti P (2014) Assembly of photosynthetic apparatus in Rhodobacter sphaeroides as revealed by functional assessments at different growth phases and in synchronized and greening cells. Photosynth Res 122:261-273

Kis M, Sipka G, Asztalos E, Rázga Z, Maróti P (2015) Purple nonsulfur photosynthetic bacteria monitor environmental stresses. J Photochem Photobiol B 151:110-117

Kocsis P, Asztalos E, Gingl Z, Maróti P (2010) Kinetic bacteriochlorophyll fluorometer. Photosynth Res 105:73-82

Labrenz M, Druschel GK, Thomsen-Ebert T, Gilbert B, Welch SA, Kemner KM, Logan GA, Summons RE, De Stasio G, Bond PL,
Lai B, Kelly SD, Banfield JF (2000) Formation of sphalerite $(\mathrm{ZnS})$ deposits in natural biofilms of sulfate-reducing bacteria. Science 290:1744-1747

Langston WJ, Bebianno MJ (1998) Metal metabolism in aquatic environments. Springer Science \& Business Media, Berlin

LaVoie SP, Mapolelo DT, Cowart DM, Polacco BJ, Johnson MK, Scott RA, Miller SM, Summers AO (2015) Organic and inorganic mercurials have distinct effects on cellular thiols, metal homeostasis, and Fe-binding proteins in Escherichia coli. J Biol Inorg Chem 20(8):1239-1251

Le Faucheur S, Tremblay Y, Fortin C, Campbell PGC (2011) Acidification increases mercury uptake by a freshwater alga Chlamydomonas reinhardtii. Environ Chem 8(6):612-622

Liehr SK, Chen H-J, Lin S-H (1994) Metals removal by algal biofilms. Water Sci Technol 30:59-68

Ma Z, Jacobsen FE, Giedroc DP (2009) Metal transporters and metal sensors: how coordination chemistry controls bacterial metal homeostasis. Chem Rev 109(10):4644-4681

Mailman M, Stepnuk L, Cicek N, Bodaly RA (2006) Strategies to lower methyl mercury concentrations in hydroelectric reservoirs and lakes: a review. Science of the total. Sci Total Environ 368(1):224-235

Malik A (2004) Metal bioremediation through growing cells. Environ Int 30:261-278

Maróti P, Wraight CA (1988) Flash-induced $\mathrm{H}^{+}$binding by bacterial photosynthetic reaction centers: comparison of spectrometric and conductometric methods. Biochim Biophys Acta 934:314-328

Matsushita T, Hirata H, Kusaka I (1988) Calcium channel blockers inhibit bacterial chemotaxis. FEBS Lett 236(2):437-440

Mehta SK, Gaur JP (2005) Use of algae for removing heavy metal ions from wastewater: progress and prospects. Crit Rev Biotechnol 25:113-152

Milano F, Dorogi M, Szebényi K, Nagy L, Maróti P, Váró Gy, Giotta L, Agostiano A, Trotta M (2007) Enthalpy/entropy driven activation of the first interquinone electron transfer in bacterial photosynthetic reaction centers embedded in vesicles of physiologically important phospholipids. Bioelectrochemistry 70:18-22

Moore MD, Kaplan S (1994) Members of the family Rhodospirillaceae reduce heavy metal oxyanions to maintain redox poise during photosynthetic growth. ASM News 60:17-23

Munoz R, Guieysse B (2006) Algal-bacterial processes for the treatment of hazardous contaminants: a review. Water Res 40(15):2799-2815

Nabi S (2014) Toxic effects of mercury. Springer, New Delhi, p 268

Najera I, Lin CC, Kohbodi GA, Jay JA (2005) Effect of chemical speciation on toxicity of mercury to Escherichia coli biofilms and planktonic cells. Environ Sci Technol 39(9):3116-3120

Nevo Y, Nelson N (2006) The NRAMP family of metal-ion transporters. Biochimica et Biophysica Acta 1763: 609-620

Patra M, Sharma A (2000) Mercury toxicity in plants. Bot Rev 66(3):379-422

Puranik PR, Paknikar KM (1999) Biosorption of lead, cadmium, and zinc by Citrobacter strain MCM B-181: characterization studies. Biotechnol Prog 15:228-237

Ren D, Navarro B, Xu H, Yue L, Shi Q, Clapham DE (2001) A prokaryotic voltage-gated sodium channel. Science 294(5550):2372-2375

Schaefer JK, Rocks SS, Zheng W, Gu B, Liang L, Morel FMM (2011) Active transport, substrate specificity, and methylation of $\mathrm{Hg}(\mathrm{II})$ in anaerobic bacteria. Proc Natl Acad Sci USA 108:8714-8719

Sigel H, Sigel A, eds. (2009) Metallothioneins and related chelators (metal ions in life sciences). Metal ions in life sciences 5. Royal Society of Chemistry, Cambridge, ISBN 1-84755-899-2

Singh A, Kuhad RC, Ward OP (2009) Biological remediation of soil: an overview of global market and available technologies. Advances in applied bioremediation. Springer, Berlin 
Siström WR (1962) The kinetics of the synthesis of photopigments in Rhodopseudomonas sphaeroides. J Gen Microbiol 28:607-616

Sloof JE, Viragh A, Vanderveer A (1995) Kinetics of cadmium uptake by green-algae. Water Air Soil Pollut 83(1-2):105-122

Spoering AL, Lewis K (2001) Biofilms and planktonic cells of Pseudomonas aeruginosa have similar resistance to killing by antimicrobials. J Bacteriol 183:6746-6751

Steunou AS, Liotenberg S, Soler M-N, Briandet R, Barbe V, Astier Ch, Ouchane S (2013) EmbRS a new two-component system that inhibits biofilm formation and saves Rubrivivax gelatinosus from sinking. Microbiol Open 2(3):431-446

Teitzel G, Parsek M (2003) Heavy metal resistance of biofilm and planktonic Pseudomonas aeruginosa. Appl Environ Microbiol 69:2313-2320

Théraulaz F, Thomas OP (1994) Complexometric determination of Mercury(II) in waters by spectrophotometry of its dithizone complex. Mikrochim Acta 113:53-59
Torres M, Goldberg J, Jensen TE (1998) Heavy metal uptake by polyphosphate bodies in living andkilled cells of Plectonema boryanum (Cyanophyceae). Microbios 96:141-147

Turksen, Kursad (Ed.) (2015) Bioprinting in regenerative medicine. Springer International Publishing, Berlin. doi:10.1007/978-3-319-21386-6\$4

Vijayadeep C, Sastry P (2014) Effect of heavy metal uptake by E. coli and Bacillus sps. J Bioremediation Biodegr 5:238

Wiener JG, Krabbenhoft DP, Heinz GH, Scheuhammer AM (2003) Ecotoxicology of mercury, Chap. 16. In Hoffman DJ, Rattner BA, Burton GA, Cairns J (eds) Handbook of ecotoxicology, 2nd edition. CRC Press, Boca Raton, pp. 409-463

Winkelmann G, Winge DR (1994) Metal ions in fungi. Marcel Dekker, Inc, New York

Youssef NH, Couger MB, McCully AL, Criado AEG, Elshahed MS (2015) Assessing the global phylum level diversity within the bacterial domain: a review. J Adv Res 6(3):269-282 